International Journal of Linguistics, Literature and Culture
Available online at https://sloap.org/journals/index.php/ijllc/
Vol. 5, No. 6, November 2019, pages: 36 47
$\begin{aligned} & \text { ISSN: 2455-8028 } \\ & \text { https://doi.org/10.21744/ijllc.v5n6.756 }\end{aligned}$

\title{
The Stylistics Analysis of the Poem "Raqeeb Se, To the Rival" by Faiz Ahmed Faiz
}

\section{Article history:}

Received: 27 May 2019

Accepted: 31 July 2019

Published: 29 November 2019

\section{Keywords:}

Faiz;

grammatical level; graphological;

lexical level;

phonological level;

style;

stylistics;

\begin{abstract}
This study examines the stylistic construction of the poem Raqeeb se "To the Rival" from "Remonstrance" [Naqsh-e-Faryaadii], in which the study unsnarled various literary devices used by Faiz that reveals the style of the poet and aids in understanding the meaning of the text. The present study is comprehensive account of the content, style and the whole language system running in the poem achieved via close reading of the text. The stylistics is done under the aspect of graphological, grammatical, syntactical, phonological patterns. The study via stylistics reveals the pathos and bleakness immersed in the overall tone of the poem. The overarching theme that pervades through the first part of the poem and culminates in to second, is sense of loss and deprivation, which the poet first feels for himself and then for the less privileged underclass. Since poetry of Faiz exposes the themes of ideology and power relations, political inequality, economical monopoly, social disorder, and how these conditions are created, imposed and put forwarded by particular power groups and some organized institutions. To answer these all questions, the study looks beyond the surface level and closely probe into the situations which are nurtured and developed over a time. To move beyond surface, all those literary devices which are in the poem construct hidden meaning of the world phenomena. This type of analysis assist readers to also reveal versatility of poet that how the personal loss of a poet amalgamates with harsh realities of his respective age.
\end{abstract}

2455-8028 ${ }^{\circledR}$ Copyright 2019. The Author. This is an open-access article under the CC BY-SA license (https://creativecommons.org/licenses/by-sa/4.0/) All rights reserved.

\section{Author correspondence: \\ Rashid Chandio, \\ Department of English \\ Shaheed Benazir Bhutto University, Sindh, Pakistan. \\ Email address: Rashidchandio92@gmail.com}

${ }^{\text {a }}$ Shaheed Benazir Bhutto University, Sindh, Pakistan

${ }^{\mathrm{b}}$ Shaheed Benazir Bhutto University, Sindh, Pakistan

${ }^{c}$ University Tun Hussein Onn Malaysia, Parit Raja, Malaysia

${ }^{\mathrm{d}}$ University of Sindh Jamshoro, Sindh, Pakistan 


\section{Introduction}

Faiz is sublime poet, moral teacher, conscious editor, strong supporter of liberty and freedom of the masses, harsh critic, eye-catching progressive writer, winner of Lenin Peace prize award, nominated two times for noble prize in literature but didn't get. He is fundamentally Urdu poet and authored eight books of poetry. His poetry and themes vary from minor subjects to the universal issues and subjects of the universe. His poetry has universal appeal that begins from the sub-continent and spread all over the world. Faiz, one of the conscious poets of his age and fought hard war against slavery, inequality and exploitation of the people. His such ideology of poetry and universal message ranked him to stand with the great poets like Pablo Neruda, Nizam-e-Hikamat and Louis Aragon. There is a sublimity in poetry of Faiz, either its nazam or ghazal Faiz excels in both and intensity of ideas lurks equally in nazam and ghazal.

He belonged to the progressive movement, collective of writers and poets who in the decade Up the 1947 independence of India and Pakistan, which epitomize a revolutionary aesthetic. Moreover, his poetry reflected syncretic spirit. Beside his poetry had profound influence on many local traditions and cultures. Poets like Faiz are warriors and act like Conscience of their times furthermore his poetry is considered rich with classical theme of Ghalib and Iqbal which acquired features of love and patriotism, and excelled in both Nazam and ghazal form of poetry that blaze a trail of love and revolution.

\section{Style}

The word style is taken from Latin language "Elocution", that means style and calls lexis in Greek terminology. Style is the broader term itself which has got multiple meanings and used in various ways by writer and commoners altogether. Style is not just limited to literature but it has wide sphere outside literature too. Strictly speaking, everything that appears on the surface is also known as style. It also reflects thoughts, ideas, opinions and hidden perceptions of an individual including authors. In literature, specifically, style becomes voice of writer that unfolds through selection of words, usage of phrases, presentation of sentences, manner of tone and these all jointly show the readers what writer wants to convey or intend to say.

\section{Stylistics}

Stylistics is the branch of applied linguistics which studies aesthetic use of language in text and literature as a whole. Predominantly, it concerns with the text's conversion, diversion, manipulation of subjects, as Kinneavy (1971), says, such stylistics prolongs and expands the study of literary discourse. Moreover, it links verbal texture with other discourse varieties. (Crystal \& Davy, 1969; Bahri et al., 2018). Stylistics plays the role of mediation between disciplines of linguistics and other literary discourses or criticism and applies various methods and insights of linguistics which helps to do literary analysis and exposes literary text from every angle. Therefore, some linguists prefer to call it "Linguistics Criticism" (Fowler, 1986; utfi Hussein \& Ali Dawood, 2018; Zaidi, 2016); others call it "Literary Linguistics" (Fabb et al., 1987; Rahman, 2018).

This type of language and linguistics studies emerged in early $20^{\text {th }}$ century with emergence and work of Russian Formalists encompassing Osip Brik, Roman Jakobson, Victor Shklovskij, Boris Ejxenbaum, Boris Tornashevskij, and Jurij Tynjanov; Romance philologists including Charles Bally, Leo Spitzer, Karl Vossler, Eric Auerbach, and Ernst Curtius; Czech Structuralists like Bohuslav Havranek, and Jan Mukalovsky; British Semanticists such as I. A. Richards and William Empson; and American new critics such as John Crowe Ransom, T. S. Eliot, Ezra Pound, and Cleanth Brooks. However, these groups invariably differed in subject and use of methods in their respective discipline. They collectively declared significance of linguistics form to literary production and its response and importance of aesthetic utilization of language in non-literary discourse. It was greatly a shocking or sharped departure from historical/philological and ideational/cultural representation to language and literature which existed over there. Many linguists conducted or produced their stylistics studies at that time which are still unchallenged and unsurpassed such as Richard's tenor-vehicle analysis of metaphor, Tomashevskij's statistical treatment of stress and word limitation in verse, and Empson's theory of lexical semantics in verse so on and so forth.

\section{Levels of Stylistics}

While making stylistics analysis, its levels are following as,

Chandio, R., Fatima, S., Tarique, T., \& Soomro, S. (2019). The stylistics analysis of the poem "raqeeb se, to the rival" by Faiz Ahmed Faiz. International Journal of Linguistics, Literature and Culture, 5(6), 36-47. https://doi.org/10.21744/ijllc.v5n6.756 
1) Phonetic level: it best explains the way speech sounds are produced and generated generally in language and particularly in a piece of writing. These further studies the features and possible value of sounds.

2) Phonological level: it systematically studies the sound pattern system of any language; the formal rules of pronunciation. It further deals with poetic devices and figures of speech such as rhyming scheme, rhythm, assonance, parallelism, consonance, and alliteration.

3) Graphological level: It mainly concerns and comprises punctuation marks and symbols very often utilized for partition of phrases and sentences; paragraphing, division occurs in text and cut the text into section depending upon related subjects. According to Crystal and Davy, Graphology discusses complete writing system of language such as punctuation marks and paragraphing as well as shaping. Graphology further contains foregrounding of use of all language patterns including quotation marks, periods, hyphens, ellipses, special structure, the full stop, contracted forms, the coma, the colon, the question marks, the semicolon, lowercase letters, capitalization, the dash, italics, small print spacing etc.

4) Grammatical level: this study both syntactic and morphological level. The main purpose is to evaluate the internal structure of the sentences in a language. These sentences function and tells about sequences of structure of the words in the sentences, various clauses, function of phrases, words, nouns, verbs etc. this needs to be categorized and lay through comprehensive analysis to unfold foregrounding and deviation within it.

5) Lexical level: This level focuses on everything that comes under the umbrella of words categories. This has been categorized into two different domains like close class words: this comprises very small group of words including determiners, conjunctions, prepositions, pronouns, etc., these all words categories fall in close class words. Another category is open class words in which nouns, verbs, adjectives and adverbs fall. There are some other features that are part of lexical level, as synonyms, antonyms, hyponyms, figures of speech, ellipses and so on.

\title{
Important characteristics of Faiz's poetry
}

\section{1) Romance}

Faiz is the most famous poet of his generation, particularly of Urdu literature and generally of world literature. Faiz is read by all sorts of readers and graph of his popularity stays stable and grows as times passes and as critics studies him in depth. Love is recurring and most excited theme and characteristics of his poetry which hangs around him and makes him so strong in every path of his life. The peculiarity of poems and ghazals is this that if a poem or ghazal begins from love or longing for beloved then it will definitely lead poem or ghazal to define helplessness of poor and will raise voice for rights of the poor as lines from one poem,

\author{
"Every pathway \\ leads to the door of your love; \\ Every word of desire: \\ the sound of your footsteps. \\ It is neither the punishment of events, \\ nor the tyranny of adversaries. \\ This tyranny, we have inflicted ourselves \\ on our poor untamed heart. \\ We are trapped in the prison \\ of the longing for our beloved; \\ We wear neither handcuff, \\ nor are shackled".
}

This depicts how Faiz longs for love even the punishment, adversaries, prison, they do not shake his confidence and his poetry and poem continues in such harsh conditions to appeal for some cause, for some commitment, for some purpose. For some freedom, for some ideal to achieve. When the parameters and principles of love turns from personal to social cause then it leaves readers to know that how much conscious poet Faiz is because that diversion is not unintentional but intentional and there is something huge in it that makes Faiz poet of the world not of a nation. Poetry of Faiz is what he says directly through words on the surface but there is hidden meaning behind all those words which are needed to be exposed then one can understand the greatness of Faiz, as Merleau-Ponty points out,

"But what if language speaks as much by what is between words 
as by the words themselves? As much what it 'does not say' as by

what it 'says'!"

\title{
2) Revolution
}

Faiz is not poet of his nation but there is universal appeal in his poetry and his poetry is very much rooted in the struggle of the world order. His poetry took him all over the world and much has been written and said about Faiz so far and work is still in progress to unfold Faiz completely. There is social protest, revolutionary zeal, standing against repression, exploitation of underprivileged class, struggle of poor, fight for equality, such are multi-dimensions of his revolutionary poetry that Faiz undertakes in his hands make them so much effective that everybody associates themselves with his poetry. This ideology and ideological project directly unravel his intention and conscious act of Faiz to speak for those whose voices are suppressed violently.

The judgment of Faiz friend Sajjād Zahīr in this matter might appear to be set a tone today, but it is nevertheless true:

\author{
"the values represented by the poet are the same as the values of all \\ progressive humanity of today. But Faiz has adopted them so well that \\ they neither appear distinct from the best traditions of our civilization \\ and culture, nor is the individuality of the poet, his soft, sweet, and \\ lyrical style divorced from them"
}

(1984, 1983)

What Vasilieva tells us about the story of Faiz. She portrays life of Faiz within the domain of intellectual fluxes on which life of Faiz is modeled and his revolutionary ideas put forward towards struggle of colonialism, fascination of Marxism, union with progressive writers' movement and fight of the left in Pakistan in the malicious context of the cold war.

Art has no boundary and artist is the ambassador of all those people who longs for help and its duty of artist to answer them where ever they belong to or from but an artist has to be universal and cure world with their art. Faiz has all those capabilities to listen all those voices and answer them with his art. This is the reason he is not local, regional, national, but an international poet.

In his own words,

"as a writer or artist, even though I run no state and command no power, I am entitled to feel that I am my brother's keeper and my brother is the whole of mankind. And this is the relevance to me of Peace, of freedom, of detente and the elimination of the nuclear menace. But out of this vast brotherhood, the nearest to me and the dearest are the insulted and the humiliated, the homeless and the disinherited, the poor, the hungry and the sick at heart. And this is the relevance to me of Palestine, of South Africa, of Namibia, of Chile, of my own people and people like mine".

\section{3) Socialism}

Concept of socialism is propounded by Karl Marx which can be defined as a set of political-historical and economic theories that directs social change through class struggle. The age in which Faiz began to write his poetry was an age social upheaval, political hegemony and economical differences, most importantly economical structure endorsed and divided the masses into class system. Such conditions laid Faiz to write his first political poem "Mujh se Pehle si Mohabbat Mere Mehboob na Maang" (Don't Ask for More Love), in which he kept his agony of personal love and longing aside and addressed very serious and bigger issues like pain and miseries of the masses.

Faiz soon realized that it's just to get freedom from British rule that will lead country to run on smooth track but qualitative change in socio-political system lied in smooth treatment and distribution of goods and services within a country. The lines from his celebrated poem "Subh-e-Azadi" Dawn of Freedom mirrors disillusionment of the poet with the long walk of freedom and liberty from ruling class. "This discolored light, this night-bitten dawn/This is not the dawn we rested for" (Kamal and Hasan 102).

In post-independence era, Faiz held the basis of his poetry to give poetic voices for powerless masses of the society and to triumph over the ruling class who suppress oppressed class pitilessly. This faith and worry for people held Faiz and his pen to stand up and voiceless voices of oppressed class must be heard from far and wide. This is the reason that Dr Siddiqui calls Faiz: Dard aur Darmaan ka Shair (Faiz Ahmed Faiz: Poet of Pain and Cure) envisages Faiz as "the poet of pain and cure: theory and practice" (2011: 10).

Themes of the poem

Chandio, R., Fatima, S., Tarique, T., \& Soomro, S. (2019). The stylistics analysis of the poem "raqeeb se, to the rival" by Faiz Ahmed Faiz. International Journal of Linguistics, Literature and Culture, 5(6), 36-47. https://doi.org/10.21744/ijllc.v5n6.756 
There are four main themes of the poem "Raqeeb Se, To the Rival"

1) Imagination of the poet

2) Beloved's beauty

3) Empathy for oppressed class

4) Pain

\section{Imagination of the poet}

Imagination plays a vital role for any poet to compose his or her poetry. All the English Romantic poets equally use and share imagination in their poetry with various definitions like Coleridge focuses on "Secondary imagination of the poet", Wordsworth imagination in his "recollection of emotions and thoughts in tranquility", According to Blake: "We do not want either Greek or Roman models if we are but just and true to our own imaginations", Keats "imagination is in his availability of beauty in everything". Faiz's imagination is reflecting from his memory of beloved's beauty like "memories of that fair one twine" "fairies nursery", these are some of the lines that discloses poets power of imagination and this continues throughout the poem. When imagination of poet reaches at its peak then poet "let the world go by", this shows how poet disconnects from his real world for the sake of attaching himself with his beloved in his imagination.

\section{Beloved's Beauty}

It's not a coincidence with Faiz when it comes to poetry that revolves around his imaginative beloved because Faiz has got so much strong connection with his characters in poetry. In the same flow, Faiz has struck with his beloved's beautiful characteristics and discuss them in the beginning of the poem that leads further Faiz to amalgamate himself with pains of those who are suppressed, exploited, tortured and killed and left alone and thrown in the corner. Lines from poem like "her youth time deigned to tread". More lines, "you who have known that cheek, those lips, that brow under whose spell I fleeted life away, you whom the dreamy magic of those eyes has touched, can tell where my years ran astray". From Such description of beauty one can predict that how Faiz carries his poetic vision and connects it with harsh realities of that age.

\section{Empathy for oppressed class}

one of the most recurring themes of Faiz's poetry is empathy for the oppressed class. This makes Faiz the poet of all those who have been under pressure and degraded by society. The war of have and have is clearly evident in Faiz's poetry. The war that started with contradiction of two cold ideologies capitalism and socialism. On the one hand, capitalism engenders the idea of class system, making class distinction in which few enjoys everything and rest of the world at bay; on the hand socialism that inculcates the idea of equality and distribution of everything would be done on merit and intellectual basis. Faiz supported Socialism because he believes in equality, liberty, and absolute freedom of masses. In this poem, same ideology has been unfolded like lines from poem,

"I learned of misery, helplessness, despair, I learned to be the friend of suffering creatures, I came to know the torment of oppressed, The truth of sobbing breath and livid features".

Faiz's personal love and romance teaches him some lessons about misery and helplessness of poor class who are struggling and fighting for their survival.

Pain

Faiz is at his best when he mingles and shares others pain. This is the stage where any writer climbs top the hill because he or she realizes that pain people go through and takes it as his or her own pain. Faiz is so sensitive poet in this regard that through his poetry, he consoles, adores and cures internal and external pain of the oppressed. Few lines from the poem where Faiz mourns and his heart leaps up,

\footnotetext{
"When laborer's flesh is sold in chaffering street,

Or pavements run with poor men's blood, a flame That lurks inside me blazes up beyond All power quenching; do not ask its name".
} 


\section{Materials and Methods}

This part will discuss stylistics analysis of the poem "Raqeeb Se, To the Rival by Faiz Ahmed Faiz". in this regard the syntactic patterns and choices, phonological, graphological, morphological levels of analysis are going to formulate the basis of analysis in this study.

\section{Results and Discussions}

What's up with the title?

"Raqeeb Se", is a one-of a great lyric poem written by Faiz Ahmed Faiz which is addressed by a man to another, who was in love with the same woman. "Raqeeb Se", seems more romantic lyric poem in the early part in which poet recalls his memories and time that he spent in thinking about his beloved and her beauty and later part reminds us about Faiz's empathy and understanding of the oppressed class. This poem is everlasting acrimony between the lovers of same person and then turned it into a relationship of sympathy and awareness of pain of oppressed class of the society as a whole.

\section{"Raqeeb Se, To the rival" as a Lyrical Poem}

We can say that this poem is lyrical because it is fairly a short and consists thirty-two lines; total eight stanzas and each stanza contains four lines. The poet expresses his feelings and emotions to his rival in the first part of the poem and then turns from his subjectivity to the objective world where injustice is going on. All these are the qualities of a lyrical poem.

\section{Graphological level}

a) There is a division of stanzas.

b) The poem is a whole written as a lyrical.

c) The poem is rich in imagery.

d) There is a usual capitalization.

e) We can see the punctuation marks in the poem

For example: Full stop, Comma, Colon, Semi-Colon, Hyphen, Sign of question mark is used in the poem.

Lexical level

Table 1

Lexical level

\begin{tabular}{|c|c|c|c|c|}
\hline Nouns & Pronouns & Common nouns & Collective nouns & Proper nouns \\
\hline $\begin{array}{l}\text { Memories, heart, fairies, } \\
\text { nursery, toils, age, tale, } \\
\text { pride, beauty, pageant, } \\
\text { dress, roof, cheek, brow, } \\
\text { counting, misery, } \\
\text { helplessness, despair, } \\
\text { torment, truth, friendless, } \\
\text { crouch, wail, flesh, blood, } \\
\text { flame, power, }\end{array}$ & $\begin{array}{l}\text { You, my, your, } \\
\text { her, I, whom, } \\
\text { who, me, their, it }\end{array}$ & $\begin{array}{l}\text { Time, youth, life, } \\
\text { magic, anguish, } \\
\text { friend, vulture, } \\
\text { morsel, poor, } \\
\text { name, }\end{array}$ & $\begin{array}{l}\text { Wives, world, feet, } \\
\text { paths, eyes, breezes, } \\
\text { nights. Pangs, lips, } \\
\text { years, gifts, creatures, } \\
\text { features, tears, } \\
\text { opinions, laborers, } \\
\text { streets, pavements, } \\
\text { men, }\end{array}$ & $\begin{array}{l}\text { Perfume, } \\
\text { moonlight, spell, } \\
\text { love, passion, }\end{array}$ \\
\hline
\end{tabular}

Table 2

Grammatical level

\begin{tabular}{llll}
\hline Verb & Gerund & Adjective & Adverb \\
\hline $\begin{array}{l}\text { Round, made, caught, called, go } \\
\text { by, tread, drunk, passed, gazed, }\end{array}$ & $\begin{array}{l}\text { Worshipping, darling, } \\
\text { fading, sobbing, }\end{array}$ & $\begin{array}{l}\text { Fair, twine, busy, old, } \\
\text { familiar, deigned. Unsatisfied, }\end{array}$ & $\begin{array}{l}\text { Under, astray, } \\
\text { beyond, side by }\end{array}$ \\
\hline
\end{tabular}

Chandio, R., Fatima, S., Tarique, T., \& Soomro, S. (2019). The stylistics analysis of the poem "raqeeb se, to the rival" by Faiz Ahmed Faiz. International Journal of Linguistics, Literature and Culture, 5(6), 36-47. https://doi.org/10.21744/ijllc.v5n6.756 


\begin{tabular}{llll}
\hline $\begin{array}{l}\text { have, played, hang, rained, } \\
\text { known, fleeted away, touched, } \\
\text { tell, ran, bring, earned, speak of, }\end{array}$ & $\begin{array}{l}\text { trickling, hovering, } \\
\text { chaffering, quenching, }\end{array}$ & $\begin{array}{l}\text { still, haunted, long-done, } \\
\text { bygone, dreamy, such, keen, } \\
\text { through, suffering, oppressed, }\end{array}$ & $\begin{array}{l}\text { side, else, } \\
\text { wherever, now, }\end{array}$ \\
$\begin{array}{l}\text { grow, snatch, holde, } \\
\text { lurk, blaze up, }\end{array}$ & & $\begin{array}{l}\text { livid, cold, broad, feeble } \\
\end{array}$ & \\
\hline
\end{tabular}

\section{Grammatical level}

Use of punctuation marks, and use of question marks and question mark is only used once in a poem in $5^{\text {th }}$ stanza in which poet tells about what he has learned and lost in that love. Such philosophy of love cannot be calculated and counted and told because it is beyond explanation; it is such passion that opens gate for poet see world and its cruel attitude and behavior that exists among masses.

Use of semi colon: semi colon is used where poet reveals that how that how those darling breezes play with her beauty in which her fading perfume or scent of her dress still swings around. Moreover, poet displays what he has learnt out of that divine love which cannot told in words and spoken through discourse.

Use of full stop: poet uses full stop six time in a poem. Each full stop shows completion of stanzas.

1) Firstly, poet describes his memories are linked with beauty of his beloved and his heart turned into fairy house and whose attachment made him to forget the world and its charm.

2) Secondly, poet continues to beautify beauty of his beloved and still remembered those paths on which her intoxicated youth walked and these eyes worshipped profitlessly.

3) Thirdly, poet continues to praise his beloved now darling breezes played with fading perfume of her dress which still hangs around. That scent rains at me from night of moon and in which the pain of bygone remains.

4) Fourthly, poet now explains his own experience of attachment and asking that have you ever seen that forehead, that cheek, that lips in whose contemplation I squandered my existence. Question continues that have ever experienced the shower of those magical eyes in whose imagination I lost my life. This stanza is quite philosophical in which imagination of poet at its peak.

5) Fifthly, poet now turns from praising his beloved to his learning out of that relationship. His love teaches him various lessons like to understand meaning of despair, frustration, helplessness, affliction, suffering of the oppressed class and also protection of those poor people who are struggling for their survival in the society.

6) Finally, poet shows his pain and explains the worst condition of those masses whose tears fall asleep in their eyes without shading them on earth and eagles spreading their wings to catch those morsels which are in their hands for eating. Here eagle indicates those aristocratic class who do not want to see poor people happy and snatch their fundamental rights. Such philosophy of Faiz is clear like crystal in his poetry.

\section{Phonological level}

The poem consists thirty-two lines with following rhyme scheme.

ABABCDCDDCECFGCGHDADICDCJDCDCKDK. There are rhyming words in the poem and these are following, Paths, eyes, hangs, pangs, creatures, features, Pride, unsatisfied, earned, learned, cold, hold,

Away, astray,

Flame, name.

\section{Schemes and troops in the poem "Raqeeb Se, To the Rival"}

Schemes and troupes are figure of speech used to create a specific style of writing.

Tropes: Tropes are figures of speech carrying meaning different from their literal meanings. In the poem words like "spell", gives meaning of in whose contemplation; "years", reflects wasted life; "vulture, indicates aristocratic class who hovers to snatch the morsels from mouth of poor; "crouch and wail" shows helpless people who can raise their voices and their voices are being folded by powerful ones; flesh gives the meaning of blood of needy people who are being continuously abused and exploited.

Scheme: Schemes are figures of speech that focus on letters, word order, syntax and sounds rather than meaning of the words. 
Anaphora: Scheme in which the same words or phrases is repeated at the beginning of successive, clauses or sentences. For example,

a) I learned of misery, helplessness, despair,

b) I learned to be the friend of suffering creatures,

c) I came to know the torment of the oppressed,

d) The truth of sobbing breath and livid creatures.

The word "I" is anaphora in the poem.

Antithesis: A scheme in which contrasting words, phrases, sentences or ideas are used for emphasis. For example: love and anguish.

Metaphor: A troop in which a word or phrase is transfused from its literal meaning to stand for something else. A metaphor compares two objects or things without using the words like "like" or "as". For Example: busy age, an old wives' tale, fading perfume etc.

Simile: A troop in which comparison is introduced by using the words "like" or "as". "Like". For instance: while as her beauty's pageant passed means caravans of charms have passed. Such gifts as love and love's anguish bring, shows partnership of theirs and pain that evokes from that partnership.

Symbol: An object that stands for points to and shares in a significant reality over and beyond it.

For Example: in the poem, poet symbolizes "that cheek, those lips, that brow with sublime beauty of his beloved under whose contemplation life of poet wasted nowhere. Moreover, poet symbolizes "trickling tears", with pain and afflictions of those poor people who do not shed tears but they die in their eyes.

Imagery: It is an author's use of vivid and descriptive language to add depth to their work. It appeals to human senses to deepen the reader's understanding of the work.

In the poem, poet uses words like "misery, helplessness, despair, suffering creatures, torment of the oppressed, sobbing breath and livid creatures, laborers flesh and poor men's blood. These all words appeal directly to human senses to understand the condition of such people in the society.

Tone: Tone is the poet's attitude towards his or her subject or readers. It is similar to tone of voice but should not confused with mood or atmosphere. An author's tone might be sarcastic, sincere, humorous, melancholic, happy, sad, romantic etc. in this poem the authors poem is romantic and sad.

\section{Diction}

The word choices made by a writer can be described as
a) Formal
b) Semiformal
c) Ornate
d) Informal
e) Technical
f) Slang

Faiz's diction is traditional, formal and realistic.

\section{Atmosphere}

The overall feeling of a work which is related to tone and mood. In this poem everything here is simple, direct and clear. The poem is pervaded throughout by romantic and sympathetic mood, and of intolerable condition of poor people.

\section{Conclusion}

The study brings forth Raqeeb Say as a poem classic which has been analyzed on different stylistic levels and found to be the harmonious amalgamation of thought, feelings and style. As the poem is reflective in nature, the overall atmosphere of the poem is grim and sad. Faiz swiftly slithers down from his beloved to the capitalist culture where the proletariat class has constantly been snatched and robbed off at the hands of bourgeoisie. The study unearthed the fact that pain inflicted by the beloved to the poet becomes a ladder for Faiz to feel of the miseries and wretchedness of the poor. Faiz has fabricated a grim yet astonishingly vivid imagery where the poet is deprived of his beloved so

Chandio, R., Fatima, S., Tarique, T., \& Soomro, S. (2019). The stylistics analysis of the poem "raqeeb se, to the rival" by Faiz Ahmed Faiz. International Journal of Linguistics, Literature and Culture, 5(6), 36-47. https://doi.org/10.21744/ijllc.v5n6.756 
are the poor deprived of food and shelter. The poem has an intricate web of simile, metaphor, antithesis and several other figures of speech which makes the poem stylistically strong and apt.

\section{Conflict of interest statement}

The authors declared that they have no competing interest.

Statement of authorship

The authors have a responsibility for the conception and design of the study. The authors have approved the final article.

Acknowledgments

The author would like to thank the editor of IJLLC for their valuable time, support and advice. 


\section{References}

Bahri, S., Rusdiawan, -- \& Nuriadi, -. (2018). Comparison of expression of God in poems written by Amir Hamzah, Chairil Anwar and Sutardji Calzoum Bachri. International Journal of Linguistics, Literature and Culture, 4(3), 64-71.

Crystal, D., \& Davy, D. (1969). Investigating English style: David Crystal,... Derek Davy. London, Indiana University Press.

Fabb, N., Attridge, D., Durant, A., \& MacCabe, C. M. (Eds.). (1987). The linguistics of writing: Arguments between language and literature. Manchester: Manchester University Press.

Fowler, R. (1986). Linguistic criticism. Oxford University Press, USA.

Kinneavy, J. L. (1971). A theory of discourse: The aims of discourse.

Lutfi Hussein, A., \& Ali Dawood, Z. (2018). Salient socio-stylistic traits of English and Arabic junior songs. International Journal of Linguistics, Literature and Culture, 4(4), 86-102. https://doi.org/10.21744/ijllc.v4n4.270

Rahman, B. (2018). The stylistics of text: wasiat renungan masa pengalaman baru. International Journal of Social Sciences and Humanities, 2(3), 149-155. https://doi.org/10.29332/ijssh.v2n3.225

Zaidi, A. (2016). The psychoanalytical reading of some selected poems of robert browning. International Journal of Linguistics, Literature and Culture, 2(4), 5-14. 


\section{Biography of Authors}

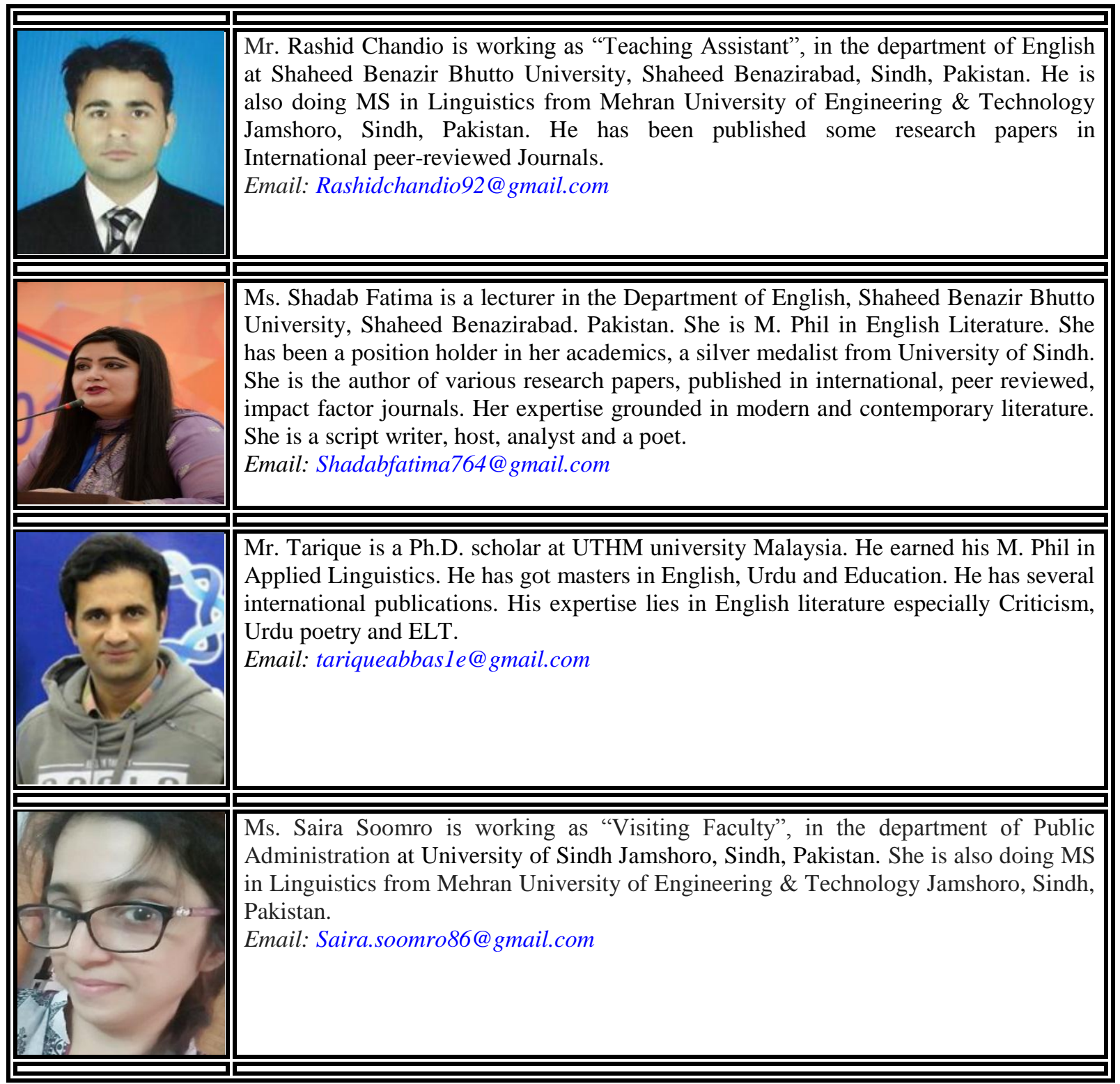




\section{APPENDIX: "To the Rival"}

Round you my memories of that fair one twine

Who made my heart a fairies' nursery,

Caught in whose toils I called this busy age

An old wives' tale, and let the world go by.

Familiar with your feet too are those paths

Her youthtime deigned to tread, drunk with youths' pride,

While as her beauty's pageant passed, these eyes

Gazed on it worshipping, unsatisfied.

With you too have those darling breezes played Where fading perfume of her dress still hangs,

On you too from her roof has rained that moonlight

Haunted by long-done nights and bygone pangs.

You who have known that cheek, those lips, that brow

Under whose spell I fleeted life away,

You whom the dreamy magic of those eyes

Has touched, can tell where my years ran astray.

Such gifts as love and love's keen anguish bring, Gifts beyond counting, side by side we earned;

To whom else could I speak of what that passion

Cost me, or through that passion what I learned?

I learned of miseries, helplessness, despair, I learned to be the friend of suffering creatures, I came to know the torment of the oppressed,

The truth of sobbing breath and livid features.

Wherever now the friendless crouch and wail Till in their eyes the trickling tears grow cold, Or where the vulture hovering on broad pinions Snatches the morsel from their feeble hold.

When laborers' flesh is sold in chaffering streets, Or pavements run with poor men's blood, a flame That lurks inside me blazes up beyond All power of quenching; do not ask its name.

Faiz Ahmed Faiz

Translated by Victor Kiernan

(A well-known British Marxist historian and scholar)

Chandio, R., Fatima, S., Tarique, T., \& Soomro, S. (2019). The stylistics analysis of the poem "raqeeb se, to the rival" by Faiz Ahmed Faiz. International Journal of Linguistics, Literature and Culture, 5(6), 36-47. https://doi.org/10.21744/ijllc.v5n6.756 